\title{
Studies on the Different Reaction Pathways between 3-Acetyl-5-benzoyl-6-methyl-2-phenyl-4H-pyran-4-one and Alkylamines
}

\author{
Hasan Genç, ${ }^{*}$ Meltem Tan, ${ }^{\dagger}$ Selçuk Gümüş, ${ }^{\dagger, *}$ Nurettin Mengeş, ${ }^{\dagger}$ İshak Bildirici, ${ }^{\dagger}$ and Ahmet Şener ${ }^{\dagger}$ \\ Yuzuncu Yil University, Faculty of Education, Department of Sciences, 65080, Kampüs, Van, Turkey \\ *E-mail: h_genc2000@yahoo.com (Experimental Results) \\ ${ }^{\dagger}$ Yuzuncu Yil University, Faculty of Arts and Sciences, Department of Chemistry, 65080, Kampüs, Van, Turkey \\ *E-mail: gumuss@gmail.com (Theoretical Results) \\ Received June 3, 2010, Accepted August 3, 2010
}

\begin{abstract}
3-Acetyl-5-benzoyl-6-methyl-2-phenyl-4H-pyran-4-one has been subjected to condensation with a series of primary amines (ethylamine - octylamine) to clarify the proposed mechanism in our previous study. The reactions of the shorter amines of the series (ethylamine - butylamine) yielded unsymmetric pyridinone products, whereas the other amines (pentylamine - octylamine) yielded symmetrical pyridinones. The starting material and the products as well as the intermediates have been subjected to theoretical analysis by quantum chemical calculations at B3LYP/6-31G(d,p) level, which provided supporting data for the experimental findings.
\end{abstract}

Key Words: Heterocyclic compounds, Pyranones, Pyridinones, Quantum chemical calculations

\section{Introduction}

Heterocyclic systems occur in a wide variety of natural and synthetic compounds that are essential to life in various ways. ${ }^{1-3}$ Many heterocyclic compounds are biosynthesized by animals and plants, and are biologically active. ${ }^{4}$

Six-membered nitrogen heterocycles are key units in medicinal chemistry and very interesting intermediates in organic synthesis. ${ }^{5}$ For example, 4 -pyrones that are oxygen containing six-membered heterocycles have been known as precursors for the synthesis of $4(1 H)$-pyridinones for almost a century. ${ }^{6}$ The synthesis of $4(1 H)$-pyridinones have attracted considerable research interest from organic chemists due to their various pharmacological effects like being antibacterial, ${ }^{7}$ antifungal, ${ }^{8}$ anti-malarial, ${ }^{9}$ cardiotonic agents, ${ }^{10}$ antihypertensive, ${ }^{11}$ antineoplastic, ${ }^{12}$ anti-inflammatory, ${ }^{13}$ analgesic, ${ }^{14}$ and anti-Parkinson's disease. ${ }^{15}$

Şener et al. ${ }^{16}$ performed the synthesis 3-acetyl-5-benzoyl6-methyl-2-phenyl-4H-pyran-4-one (1a) and 3,5-dibenzoyl2,6-diphenyl-4-pyrone (1b) and used these pyrone derivatives as precursors for the synthesis of novel pyridinone systems by reacting them with various amines. When pyranone 1a was reacted with two-fold excess of one of the amines, the final product was alkylimino-4-(1H)-pyridinone; however, pyrone 1b yielded only the alkyl substituted pyridinone derivative (Scheme 1). Thus, they ended up with a conclusion that the reaction must be in two steps in the case of pyranone 1a, and the first addition is the Michael addition at the methyl substituted position of the central ring.

The aim of the present study was to react pyranone 1a with a series of primary amines in an equimolar ratio to prove the proposed mechanism. ${ }^{16}$ Moreover, the reproducibility of the reaction with longer chain primary alkylamines was examined. The amines range from $n$-ethylamine to $n$-octylamine so that the effect of the alkyl length of the amines on the product has also been investigated. Some structural and physicochemical data about the present systems have been obtained by quantum chemical calculations at the level of B3LYP/6-31G(d,p).

\section{Results and Discussion}

The present work involves the investigation of the products of the equimolar condensation reactions of pyranone 1a with primary amines ranging from ethylamine to octylamine. The summary of the results of the equimolar reactions has been shown in Scheme 2.

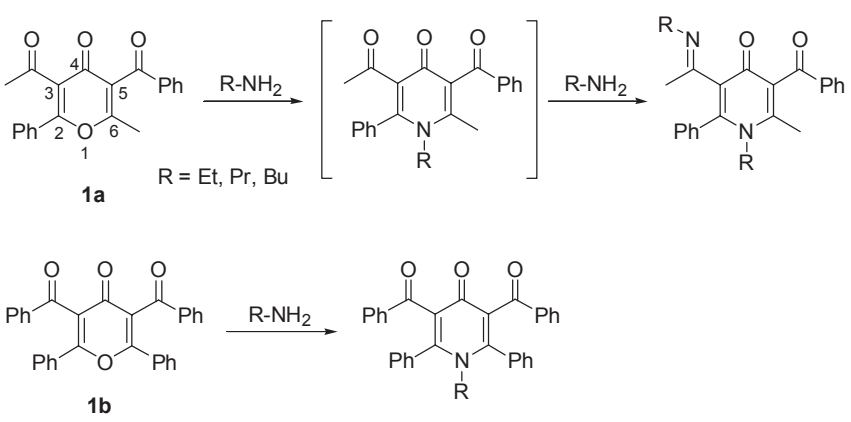

Scheme 1

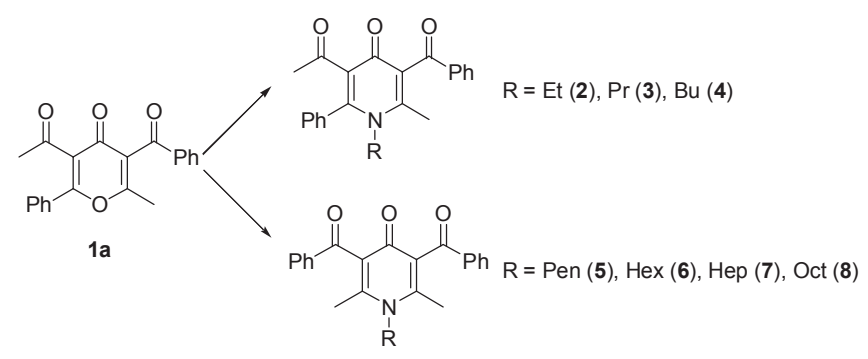

Scheme 2 


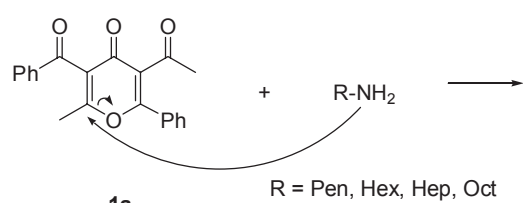

1a

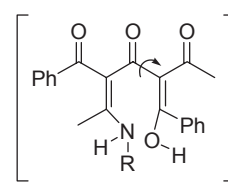

I

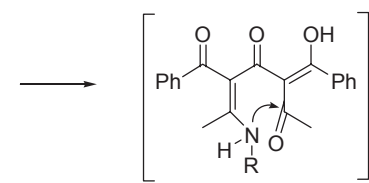

II

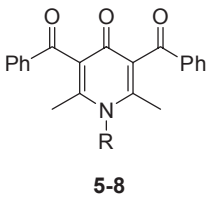

Scheme 3

The shorter amines $(\mathrm{R}=\mathrm{Et}, \mathrm{Pr}, \mathrm{Bu})$ yielded unsymmetric 3-acetyl-5-benzoyl-6-methyl-1-alkyl-2-phenylpyridin-4(1H)one derivatives of 4-pyridinone, whereas the longer amines $(\mathrm{R}=$ Pen, Hex, Hep, Oct) yielded symmetric 3,5-dibenzoyl-2,6dimethyl-1-alkyl-pyridin-4(1H)-one systems. The structure of pentyl pyridinone derivative has been confirmed by crystallographic analysis. ${ }^{17}$ This outcome leads the authors to propose the following mechanism (Scheme 3).

The first step of the reaction is the attack of the amine to the sterically less hindered, methyl substituted site $\left(\mathrm{C}_{6}\right)$ of the pyranone ring rather than at the phenyl substituted site $\left(\mathrm{C}_{2}\right)$. At this point, the length of the amine does not seem to change its nucleophilicity because the calculated Mulliken charges for ethylamine and octylamine are almost equal (-0.04). Therefore, the stability of the addition intermediate should be effective on the determination of the final product. In the case of the longer amine series the stability of the intermediate seems to be enhanced by the rotation of the acetyl moiety $\left(\mathrm{C}_{3}-\mathrm{C}_{4}\right.$ single bond). The electronic energies of "not-rotated" I and "rotated" II of the pentyl derivative 5 are calculated (B3LYP/6-31G $(\mathrm{d}, \mathrm{p})$ ) to be -1170.362672 and -1170.371339 a.u., respectively. The rotated and not-rotated conformers stand for the conformers rotated and not-rotated around the $\mathrm{C}_{3}-\mathrm{C}_{4}$ single bond after the amine attack followed by the ring opening, respectively. Therefore, the rotated conformer is favored over the non-rotated one, with 22 $\mathrm{kJ} / \mathrm{mol}$ energy difference between them. The situation appeared to be opposite in the case of butylamine $\mathbf{4}$ where the not-rotated conformer I was favored over the rotated II by a difference of $25 \mathrm{~kJ} / \mathrm{mol}$ from the calculated energies of -1129.312369 a.u. for I and -1129.3024701 a.u. for II. Moreover, in order to prove that, the steric hindrance of the amine chain forced the rotation of the $\mathrm{C}_{3}-\mathrm{C}_{4}$ single bond to end up with the symmetrical product, we compared the relative stability of the intermediates of a branched primary amine, 1,1-diethyl-propylamine. Figure 1 shows the optimized geometries for the corresponding notrotated (a) and rotated conformers (b). As seen there, although the distance between the amine and carbonyl moieties is the same (3.12 $\AA$ ) for the second attack for both cases, the crowded alkyl groups attached to the amine and the phenyl group strongly repel each other and seems to prevent the formation of the final product through the not-rotated conformer (a). Thus, the experimetal findings have been supported by the theoretical data. The structures of the synthesized compounds (2-8) have been characterized by ${ }^{1} \mathrm{H}-\mathrm{NMR},{ }^{13} \mathrm{C}-\mathrm{NMR}$, and elemental analysis (see experimental part).

The amine can add to the side chain acetyl part of the 4-pyrone derivative. The charges on $\mathrm{C}_{6}$ and at carbonyl of the acetyl were 0.132 and 0.408 (See Figure 2), respectively which favors the first attack at carbonyl of the acetyl. The attack at the acetyl carbonyl can lead to the formation of the aminal intermediate

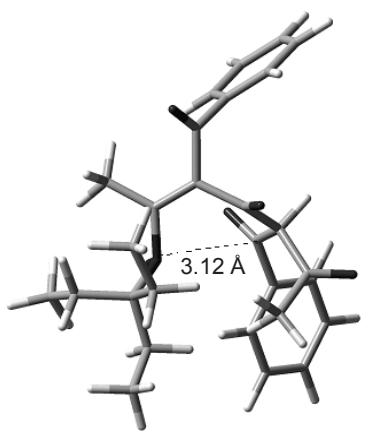

(a)

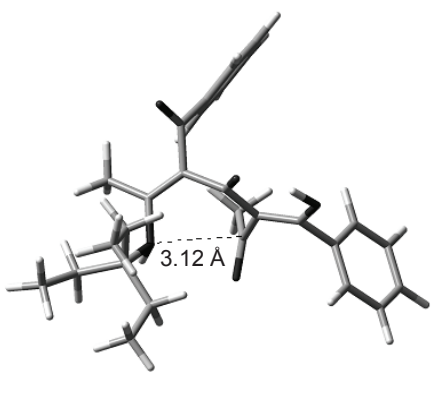

(b)
Figure 1. The geometry optimized structures of the not-rotated (a) and rotated (b) systems when the amine moiety is sterically crowded.
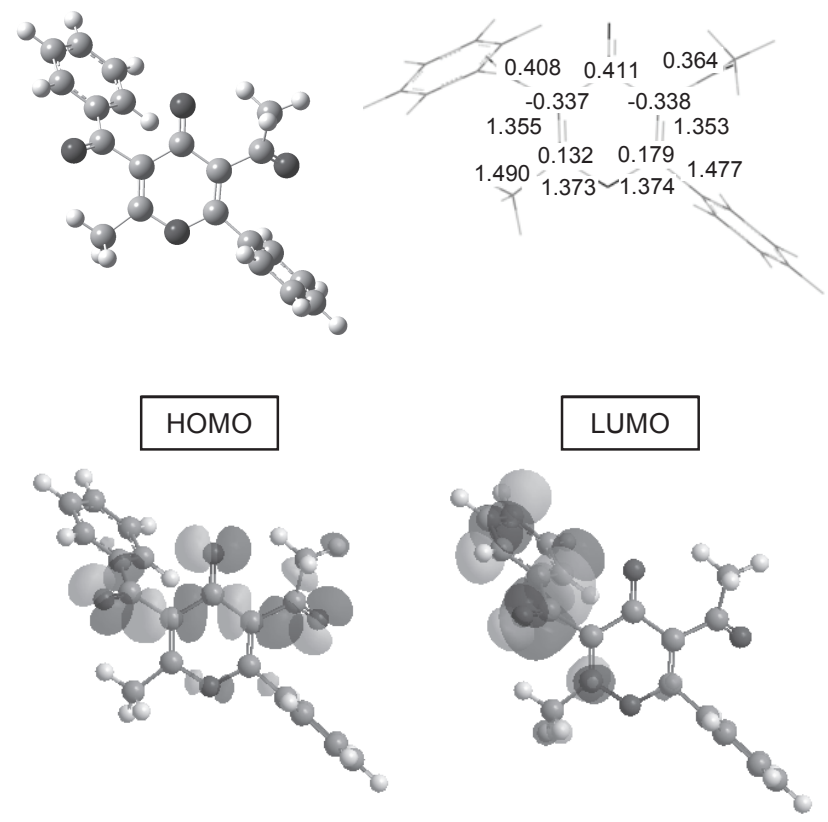

Figure 2. Geometry optimized structure, charges and some structural parameters and the HOMO and LUMO molecular orbital energy schemes of the 4-pyrone derivative.

and a subsequent dehydration process can lead to the corresponding ketimine. The aminal formation proceeds readily but the dehydration step requires a dehydrating agent or high energy. The amine attack at the pyranone ring $\left(\mathrm{C}_{6}\right)$ also leads to the aminal, which seems to readily undergo an immediate ring opening to give the intermediate I (Scheme 3), which favorably undergoes the second condensation route to form the pyridinone, instead of following a reversible process back to the starting material. Therefore, the pyridinones are the final products under 
the given conditions.

The geometry optimized structure together with the HOMO and LUMO molecular orbital energy schemes of the starting 4-pyrone 1a derivative can be seen in Figure 2. The Mulliken charges on atoms of central importance and some bond lengths have also been reported in the same figure. The phenyl moiety has been found to be almost perpendicular to the central ring so that the steric hinderance due to this big group has been somewhat maximized.

In conclusion, 3-acetyl-5-benzoyl-6-methyl-2-phenyl-4Hpyran-4-one (1a) has been reacted with amines to synthesize alkyl pyridinone derivatives. When amines with shorter alkyl chains $\left(\mathrm{C}_{4}\right.$ or shorter) were used, unsymmetrical pyridinones were obtained; whereas, amines with longer alkyl chains $\left(\mathrm{C}_{5}\right.$ or longer), symmetrical pyridinones were obtained. This outcome has been explained with a two-step mechanism in which the first addition and ring-opened intermediates undergo the bond rotation around the $\mathrm{C}_{3}-\mathrm{C}_{4}$ for the second condensation step to relieve the steric strain. Theoretical calculations at the level of B3LYP/6-31G $(d, p)$ have been carried out for an amine with a branched alkyl chain, which support the suggested explanation.

\section{Experimetal}

The ${ }^{1} \mathrm{H}$ NMR and ${ }^{13} \mathrm{C}$ NMR spectra were recorded on a ASR 18 YUICH spectrometer using $\mathrm{Si}\left(\mathrm{CH}_{4}\right)_{4}$ as the reference. Elemental analyses were performed on a Carlo Erba EAGER 200. Melting points were determined on an Electrothermal Gallenkamp apparatus.

All reagents and solvents were of reagent grade quality and were obtained from commercial suppliers. All solvents were dried by refluxing with appropriate drying agents and distilled before use. The homogeneity of the products was tested in each step by TLC $\left(\mathrm{SiO}_{2}\right)$.

3-Acetyl-5-benzoyl-6-methyl-2-phenyl-4 H-pyran-4-one (1a): Ref 16.

General procedures for pyridinone derivatives (2-8). 3-Acetyl-5-benzoyl-6-methyl-2-phenyl-4H-pyran-4-one (1) (1 mmol) and amine derivative ( $1 \mathrm{mmol}$ ) were refluxed in ethanol for 24 hours. The solvent was evaporated under reduced pressure to give an oily residue which was treated with ether and finally crystallized from indicated solvent and solvent for each compound: $\mathbf{2}$, benzene-cyclohexane; $\mathbf{3}$, ethanol:water; $\mathbf{4}$, benzenecyclohexane; $\mathbf{5}$, ethanol; $\mathbf{6}$, xylene; $\mathbf{7}$, benzene-cyclohexane; $\mathbf{8}$, ether.

3-Acetyl-5-benzoyl-1-ethyl-6-methyl-2-phenyl-4H-pyran4-one (2): Yield 10.27\%; mp $212{ }^{\circ} \mathrm{C} ;{ }^{1} \mathrm{H}$ NMR (DMSO- $d_{6}$ ) $\delta$ 7.819-7.901 (m, 5H, CH, aromatic benzoyl), 7.371-7.645 (m, $5 \mathrm{H}, \mathrm{CH}$, ring-phenyl) $1.062-1.098\left(\mathrm{t}, 3 \mathrm{H}, J=7.2 \mathrm{~Hz}, \mathrm{NCH}_{2} \mathrm{CH}_{3}\right)$, 3.747-4.121 (q, 2H, $J=7.2 \mathrm{~Hz} \mathrm{NCH}_{2} \mathrm{CH}_{3}$ ), 2.27 (s, 3H, $\mathrm{CH}_{3}-$ $\mathrm{C}=\mathrm{O}), 2.26 \mathrm{ppm}\left(\mathrm{s}, 3 \mathrm{H}\right.$, ring- $\left.\mathrm{CH}_{3}\right) ;{ }^{13} \mathrm{C}$ NMR (DMSO- $\left.d_{6}\right) \delta$ $173.302(\mathrm{C}=\mathrm{O}, \mathrm{C}-4), 196.839(\mathrm{C}=\mathrm{O}-$ benzoyl $), 201.821(\mathrm{C}=\mathrm{O}-$ acetyl), 128.786-130.246 (ring-phenyl) 132.539-147.316 (benzoyl), 43.335-44.546 (ring- $\left.\mathrm{CH}_{3}\right), 32.034\left(\mathrm{CH}_{2}-\mathrm{NCH}_{2} \mathrm{CH}_{3}\right)$, $15.381\left(\mathrm{CH}_{3}-\mathrm{NCH}_{2} \mathrm{CH}_{3}\right), 17.517-17.547$ ppm $\left(\mathrm{CH}_{3}-\mathrm{C}=\mathrm{O}\right)$. Anal. Calcd. for $\mathrm{C}_{23} \mathrm{H}_{21} \mathrm{O}_{3}$ : C, 76.86; H, 5.89; N, 3.90. Found: C, 76.81; $\mathrm{H}, 5.75 ; \mathrm{N}, 3.90$.

3-Acetyl-5-benzoyl-6-methyl-2-phenyl-1-propyl-4(1H)- pyridinone (3): Yield $46.0 \%$; mp $159{ }^{\circ} \mathrm{C} ;{ }^{1} \mathrm{H}$ NMR (DMSO- $d_{6}$ ) $\delta$ 7.508-7.898 (m, 10H, CH, aromatic), 0.542-0.579 (t, 3H, $J=$ $\left.7.2 \mathrm{~Hz}, \mathrm{NCH}_{2} \mathrm{CH}_{2}-\mathrm{CH}_{3}\right), 1.753-1.784\left(\mathrm{~m}, 2 \mathrm{H}, \mathrm{NCH}_{2}-\mathrm{CH}_{2}-\mathrm{CH}_{3}\right)$, 3.949-3990 (t, $\left.2 \mathrm{H}, J=7.2 \mathrm{~Hz}, \mathrm{~N}-\mathrm{CH}_{2}-\mathrm{CH}_{2} \mathrm{CH}_{3}\right), 2.26$ (s, 3H, $\mathrm{CH}_{3}-\mathrm{C}=\mathrm{O}$ ), $2.25 \mathrm{ppm}$ (s, $3 \mathrm{H}$, ring- $\left.\mathrm{CH}_{3}\right) ;{ }^{13} \mathrm{C}$ NMR (DMSO- $d_{6}$ ) $\delta 173.286(\mathrm{C}=\mathrm{O}, \mathrm{C}-4), 196.809(\mathrm{C}=\mathrm{O}-$ benzoyl $), 201.813(\mathrm{C}=\mathrm{O}-$ acetyl), 134.120-149.247 (ring-phenyl and benzoyl) 128.908130.104 (double bond), 49.664-50.716 (ring- $\left.\mathrm{CH}_{3}\right), 32.048\left(\mathrm{CH}_{2}-\right.$ $\left.\mathrm{N}-\mathrm{CH}_{2}-\mathrm{CH}_{2} \mathrm{CH}_{3}\right), 22.946\left(\mathrm{CH}_{2}-\mathrm{NCH}_{2}-\mathrm{CH}_{2}-\mathrm{CH}_{3}\right), 11.022\left(\mathrm{CH}_{3}-\right.$ $\left.\mathrm{NCH}_{2} \mathrm{CH}_{2}-\mathrm{CH}_{3}\right), 17.661$ ppm $\left(\mathrm{CH}_{3}-\mathrm{C}=\mathrm{O}\right)$. Anal. Calcd. for $\mathrm{C}_{24} \mathrm{H}_{23} \mathrm{NO}_{3}$ : C, 77.19; H, 6.21; N, 3.75. Found: C, 77.51; H, 6.25; $\mathrm{N}, 3.75$.

3-Acetyl-5-benzoyl-1-butyl-6-methyl-2-phenyl-4(1H)-pyridinone (4): Yield 23.3\%; mp $153{ }^{\circ} \mathrm{C} ;{ }^{1} \mathrm{H}$ NMR (DMSO- $\left.d_{6}\right) \delta$ 7.507-7.899 (m, 10H, CH, aromatic), 0.577-0.613 (t, 3H, $J=$ $\left.7.2 \mathrm{~Hz}, \mathrm{NC}_{3} \mathrm{H}_{7}-\mathrm{CH}_{3}\right), 0.948-0.984\left(\mathrm{~m}, 2 \mathrm{H}, \mathrm{NC}_{2} \mathrm{H}_{5}-\mathrm{CH}_{2}-\mathrm{CH}_{3}\right)$, 1.395-1.753 (m, 2H, NCH$\left.-\mathrm{CH}_{2}-\mathrm{C}_{2} \mathrm{H}_{5}\right), 3.988-4.029$ (t, $2 \mathrm{H}$, $\left.J=8-8.4 \mathrm{~Hz}, \mathrm{~N}-\mathrm{CH}_{2}-\mathrm{C}_{3} \mathrm{H}_{7}\right), 2.272\left(\mathrm{~s}, 3 \mathrm{H}, \mathrm{CH}_{3}-\mathrm{C}=\mathrm{O}\right), 2.255$ ppm (s, 3H, ring- $\left.\mathrm{CH}_{3}\right) ;{ }^{13} \mathrm{C}$ NMR (DMSO- $\left.d_{6}\right) \delta 172.660(\mathrm{C}=\mathrm{O}$, C-4), 196.809 (C=O-benzoyl), 201.813 ( $\mathrm{C}=\mathrm{O}$-acetyl), 134.108147.351 (ring-phenyl and benzoyl) 128.885-129.646 (double bond), 48.091 (ring- $\left.\mathrm{CH}_{3}\right), 32.055\left(\mathrm{~N}_{-}-\mathrm{CH}_{2}-\mathrm{C}_{3} \mathrm{H}_{7}\right), 31.465\left(\mathrm{NCH}_{2}-\right.$ $\left.\mathrm{CH}_{2}-\mathrm{C}_{2} \mathrm{H}_{5}\right), 19.445\left(\mathrm{NC}_{2} \mathrm{H}_{5}-\mathrm{CH}_{2}-\mathrm{CH}_{3}\right), 13.282\left(\mathrm{NC}_{3} \mathrm{H}_{7}-\mathrm{CH}_{3}\right)$, 17.637 ppm $\left(\mathrm{CH}_{3}-\mathrm{C}=\mathrm{O}\right)$. Anal. Calcd. for $\mathrm{C}_{24} \mathrm{H}_{23} \mathrm{NO}_{3}$ : C, 77.49; H, 6.50; N, 3.61. Found: C, 77.44; H, 6.50; N, 3.58.

3,5-Dibenzoyl-2,6-dimethyl-1-pentyl-4(1H)-pyridinone (5): Ref. 16 and Ref. 17.

3,5-Dibenzoyl-2,6-dimethyl-1-hexyl-4(1H)-pyridinone (6): Yield 23.0\%; mp $177{ }^{\circ} \mathrm{C} ;{ }^{1} \mathrm{H}$ NMR (DMSO- $d_{6}$ ) $\delta$ 7.505-8.033 (m, 10H, CH, aromatic), 0.871-0.904 (t, 3H, $J=6.4-6.8 \mathrm{~Hz}$, $\left.\mathrm{NC}_{5} \mathrm{H}_{10}-\mathrm{CH}_{3}\right), 1.098-1.345\left(\mathrm{~m}, 4 \mathrm{H}, \mathrm{NC}_{4} \mathrm{H}_{8}-\mathrm{CH}_{2}-\mathrm{CH}_{3}\right), 1.743-$ $2.103\left(\mathrm{~m}, 4 \mathrm{H}, \mathrm{NC}_{2} \mathrm{H}_{4}-\mathrm{CH}_{2}-\mathrm{CH}_{2}-\mathrm{C}_{2} \mathrm{H}_{5}\right), 3.984-4.024$ (t, 2H, $J=$ 7.6-8.4 Hz, $\left.\mathrm{NCH}_{2}-\mathrm{CH}_{2}-\mathrm{C}_{4} \mathrm{H}_{9}\right), 2.267$ ppm (s, 6H, ring- $\left.\mathrm{CH}_{3}\right)$; ${ }^{13} \mathrm{C}$ NMR (DMSO- $\left.d_{6}\right) \delta 173.279(\mathrm{C}=\mathrm{O}, \mathrm{C}-4), 196.809(\mathrm{C}=\mathrm{O}-$ benzoyl), 129.118-137.236 (double bond), 48.316, 31.113, 29.457, 26.190, 22.530, 17.647, 14.318 ppm (N-chain and ring- $\mathrm{CH}_{3}$ ). Anal. Calcd. for $\mathrm{C}_{27} \mathrm{H}_{29} \mathrm{NO}_{3}$ : $\mathrm{C}, 78.04 ; \mathrm{H}, 7.03 ; \mathrm{N}$, 3.37. Found: C, 78.01; H, 7.01; N, 3.34.

3,5-Dibenzoyl-2,6-dimethyl-1-heptyl-4(1H)-pyridinone (7): Yield $24.0 \%$; $\mathrm{mp} 130{ }^{\circ} \mathrm{C} ;{ }^{1} \mathrm{H}$ NMR (DMSO- $d_{6}$ ) $\delta$ 7.429-8.907 (m, 10H, CH, aromatic), 0.798-0.816 (t, 3H, $J=7.2 \mathrm{~Hz} \mathrm{NC}_{6} \mathrm{H}_{12^{-}}$ $\mathrm{CH}_{3}$ ), 0.862-1.497 (m, 8H, NC $\left.\mathrm{H}_{10}-\mathrm{CH}_{2}-\mathrm{CH}_{3}\right), 1.745-1.805$ (m, $2 \mathrm{H}, \mathrm{NC}_{2} \mathrm{H}_{4}-\mathrm{CH}_{2}-\mathrm{CH}_{2}-\mathrm{CH}_{2}-\mathrm{C}_{2} \mathrm{H}_{5}$ ), 3.982-4.022 (t, $2 \mathrm{H}, J=8$ $\left.\mathrm{Hz}, \mathrm{N}-\mathrm{CH}_{2}-\mathrm{C}_{6} \mathrm{H}_{13}\right), 2.266$ ppm (s, 6H, ring- $\left.\mathrm{CH}_{3}\right) ;{ }^{13} \mathrm{C} \mathrm{NMR}$ $\left(\mathrm{DMSO}-d_{6}\right) \delta 173.279$ (C=O, C-4), 196.809 (C=O-benzoyl), 128.878-137.206 (double bond), 48.316, 31.670, 29.509, 28.597, 26.491, 22.463, 17.649, $14.402 \mathrm{ppm}\left(\mathrm{N}\right.$-chain and ring- $\left.\mathrm{CH}_{3}\right)$. Anal. Calcd. for $\mathrm{C}_{28} \mathrm{H}_{31} \mathrm{NO}_{3}$ : C, 78.29; $\mathrm{H}, 7.27 ; \mathrm{N}, 3.26$. Found: C, 78.21; H, 7.41; N, 3.34.

3,5-Dibenzoyl-2,6-dimethyl-1-octyl-4(1H)-pyridinone (8): Yield 15.7\%; mp $122{ }^{\circ} \mathrm{C} ;{ }^{1} \mathrm{H}$ NMR (DMSO- $d_{6}$ ) $\delta$ 7.409-8.019 (m, 10H, CH, aromatic), 0.852-0.884 (t, 3H, $J=6.4 \mathrm{~Hz}, \mathrm{NC}_{7} \mathrm{H}_{14^{-}}$ $\left.\mathrm{CH}_{3}\right), 1.021-1.351\left(\mathrm{~m}, 10 \mathrm{H}, \mathrm{NC}_{6} \mathrm{H}_{12}-\mathrm{CH}_{2}-\mathrm{CH}_{3}\right), 1.743-1.810$ (m, $\left.2 \mathrm{H}, \mathrm{NC}_{2} \mathrm{H}_{4}-\mathrm{CH}_{2}-\mathrm{CH}_{2}-\mathrm{CH}_{2}-\mathrm{CH}_{2}-\mathrm{C}_{2} \mathrm{H}_{5}\right), 3.980-4.021$ (t, $2 \mathrm{H}$, $\left.J=8-8.4 \mathrm{~Hz}, \mathrm{~N}-\mathrm{CH}_{2}-\mathrm{C}_{7} \mathrm{H}_{15}\right), 2.265 \mathrm{ppm}\left(\mathrm{s}, 6 \mathrm{H}\right.$, ring- $\left.\mathrm{CH}_{3}\right) ;{ }^{13} \mathrm{C}$ NMR (DMSO- $\left.d_{6}\right) \delta 173.280(\mathrm{C}=\mathrm{O}, \mathrm{C}-4), 196.802(\mathrm{C}=\mathrm{O}$-benzoyl), 129.128-137.251 (double bond), 48.317, 31.656, 29.506, $29.097,28.903,26.536,22.515,17.645,14.410$ ppm (N-chain 
and ring- $\mathrm{CH}_{3}$ ). Anal. Calcd. for $\mathrm{C}_{29} \mathrm{H}_{33} \mathrm{NO}_{3}$ : C, 78.52; $\mathrm{H}, 7.50$; N, 3.16. Found: C, 78.41; H, 7.31; N, 3.24.

Method of theoretical calculation. The initial geometry optimizations of the title pyrone derivative and the pyridinones obtained by the condensation reaction of the starting compound and the primary amines leading to energy minima were achieved by using MM2 method followed by semi-empirical PM3 selfconsistent fields molecular orbital (SCF MO) method ${ }^{18,19}$ at the restricted level. ${ }^{20}$ Then, final geometry optimizations were performed within the framework of density functional theory (DFT, B3LYP) $)^{21,22}$ at the level of 6-31G(d,p) (restricted closedshell) without any geometrical restriciton. The exchange term of B3LYP consists of hybrid Hartree-Fock and local spin density (LSD) exchange functions with Becke's gradient correlation to LSD exchange. ${ }^{23}$ The correlation term of B3LYP consists of the Vosko, Wilk, Nusair (VWN3) local correlation functional ${ }^{24}$ and Lee, Yang, Parr (LYP) correlation correction functional. ${ }^{25}$ The BLYP method gives a better improvement over the SCF-HF results. Its predictions are in qualitative agreement with experiment. ${ }^{26-28}$ The normal mode analysis for each structure yielded no imaginary frequencies for the $3 N-6$ vibrational degrees of freedom, where $N$ is the number of atoms in the system. This indicates that the structure of each molecule corresponds to at least a local minimum on the potential energy surface.

All these computations have been performed using Gaussian 03 package programe. ${ }^{29}$

\section{References}

1. Katritzky, A. R. Handbook of Heterocyclic Chemistry; Elsevier: Gainesville, 2000.

2. Gilchrist, T. L. Heterocyclic Chemistry; Pitman: Marshfield, 1985.

3. Young, D. W. Heterocyclic Chemistry; Longman: London, 1975.

4. Sainsbury, M. Heterocyclic Chemistry; RSC Publishing: Cambridge, 2001.

5. Dong, D.; Bi, X.; Liu, Q.; Cong, F. Chem. Commun. 2005, 28, 3580 .

6. Peratoner, A. Gazz. Chim. Ital. 1906, 36, 52.

7. Erol, D. D.; Yulug, N. Eur. J. Med. Chem. 1999, 29, 893.

8. Knops, H. J.; Eue, L.; Schmint, R. R. Ger.Offen. DE 3, 210, 598 (Cl. C07D213/68), 06 Oct.1983, Chem. Abstr. 1984, 34412j, 100.

9. Hershko, C.; Theanacho, E. N.; Spira, D. T.; Peter, H. H.; Dobbin, P.; Hider, R. C. Blood 1991, 77, 637.
10. Williams, W. R. H. Can. J. Chem. 1976, 54, 3377.

11. Faith, W.; Campell, H. F.; Kuhla, D. Eur. Pat. Appl. WO 88/00468 (C07 D 401/10, C07 D 401/14, A61K 31/44) 28 January 1988.

12. Hwang, D. R.; Proctor, G. R.; Driscoll, J. S. J. Pharm. Sci. 1980, 69, 1074.

13. Hershko, C.; Theanacho, E. N.; Spira, D. T.; Peter, H. H.; Dobbin, P.; Aytemir, M. D.; Uzbay, T.; Erol, D. D. Arzneim-Forsch/Drug Res. 1999, 49(3), 250.

14. Saelens, J. K.; Bernard, P. S.; Wilson, D. E. Brain Res. Bull. 1980, $5,533$.

15. Waldmeir, P. C.; Buchle, A. M.; Steulet, A. F. Biochem. Pharm. 1993, 45, 2417.

16. Şener, A.; Eskinoba, S.; Bildirici, İ.; Genç, H.; Kasımoğulları, R. J. Heterocyclic. Chem. 2007, 44, 337.

17. Şahin, Z. S.; Işık, Ş.; Şener, A.; Tan, M. Acta Crystallogr., Sect. E: Struct. Rep. Online 2009, E65, 619.

18. Stewart, J. J. P. J. Comput. Chem. 1989, 10, 209.

19. Stewart, J. J. P. J. Comput. Chem. 1989, 10, 221.

20. Leach, A. R. Molecular Modelling; Longman: Essex, 1997.

21. Kohn, W.; Sham, L. J. Phys. Rev. 1965, 140, 1133.

22. Parr, R. G.; Yang, W. Density Functional Theory of Atoms and Molecules; Oxford University Press: London, 1989.

23. Becke, A. D. Phys. Rev. A 1988, 38, 3098.

24. Vosko, S. H.; Vilk, L.; Nusair, M. Can. J. Phys. 1980, 58, 1200.

25. Lee, C.; Yang, W.; Parr, R. G. Phys. Rev. B 1988, 37, 785.

26. Scuseria, G. E. J. Chem. Phys. 1992, 97, 7528.

27. Sosa, C.; Lee, C. J. Chem. Phys. 1993, 98, 8004.

28. Wilson, P. J.; Amos, R. D.; Handy, N. C. Phys. Chem. Chem. Phys. 2000, 2, 187

29. Frisch, M. J.; Trucks, G. W.; Schlegel, H. B.; Scuseria, G. E.; Robb, M. A.; Cheeseman, J. R.; Montgomery, J. A., Jr.; Vreven, T.; Kudin, K. N.; Burant, J. C.; Millam, J. M.; Iyengar, S. S.; Tomasi, J.; Barone, V.; Mennucci, B.; Cossi, M.; Scalmani, G.; Rega, N.; Petersson, G. A.; Nakatsuji, H.; Hada, M.; Ehara, M.; Toyota, K.; Fukuda, R.; Hasegawa, J.; Ishida, M.; Nakajima, T.; Honda, Y.; Kitao, O.; Nakai, H.; Klene, M.; Li, X.; Knox, J. E.; Hratchian, H. P.; Cross, J. B.; Adamo, C.; Jaramillo, J.; Gomperts, R.; Stratmann, R. E.; Yazyev, O.; Austin, A. J.; Cammi, R.; Pomelli, C.; Ochterski, J. W.; Ayala, P. Y.; Morokuma, K.; Voth, G. A.; Salvador, P.; Dannenberg, J. J.; Zakrzewski, V. G.; Dapprich, S.; Daniels, A. D.; Strain, M. C.; Farkas, O.; Malick, D. K.; Rabuck, A. D.; Raghavachari, K.; Foresman, J. B.; Ortiz, J. V.; Cui, Q.; Baboul, A. G.; Clifford, S.; Cioslowski, J.; Stefanov, B. B.; Liu, G.; Liashenko, A.; Piskorz, P.; Komaromi, I.; Martin, R. L.; Fox, D. J.; Keith, T.; Al-Laham, M. A.; Peng, C. Y.; Nanayakkara, A.; Challacombe, M.; Gill, P. M. W.; Johnson, B.; Chen, W.; Wong, M. W.; Gonzalez, C.; Pople, J. A. Gaussian 03, Revision B. 01, Gaussian Inc., Wallingford, CT, 2004. 